\title{
Critical Response
}

$V$

The Politics of Interpretations

\section{Gayatri Chakravorty Spivak}

It is difficult to speak of a politics of interpretation without a working notion of ideology as larger than the concepts of individual consciousness and will. At its broadest implications this notion of ideology would undo the oppositions between determinism and free will and between conscious choice and unconscious reflex. Ideology in action is what a group takes to be natural and self-evident, that of which the group, as a group, must deny any historical sedimentation. It is both the condition and the effect of the constitution of the subject (of ideology) as freely willing and consciously choosing in a world that is seen as background. In turn, the subject(s) of ideology are the conditions and effects of the self-identity of the group as a group. It is impossible, of course, to mark off a group as an entity without sharing complicity with its ideological definition. A persistent critique of ideology is thus forever incomplete. In the shifting spectrum between subject-constitution and groupconstitution are the ideological apparatuses that share the condition/ effect oscillation.

I am always obliged to quote Stuart Hall's excellent historical study of ideology whenever I refer to the notion in the U.S. context: "two radically different styles of thought-the European (where the concept [of ideology] has played a significant role) and the American (where it had up to [1949] been largely absent). . . . An interesting essay could be written on what concepts did duty, in American social theory, for the absent concept of 'ideology': for example, the notion of norms in structural functionalism, and of 'values' and the 'central value system' in 
[Talcott] Parsons." ${ }^{1}$ I would add to this list a concept of the "unconscious" as a continuous and homogeneous part of the mind that is simply "not conscious."

I will here suggest the usefulness of a broader concept of ideology and note some marks of ideology at work: conserving the sovereign subject; excluding a monolithic Marx(ism); and excluding or appropriating a homogeneous woman. The text of the symposium does not contain a hidden ideological truth but is operated by as it operates an imperfectly hidden ideological agenda; that is one of its structural alterities.

It is in Stephen Toulmin's "The Construal of Reality" that the absence of a theory of ideology is felt the most; for Toulmin's project is to undo the disciplinary-ideological opposition between the human sciences and the natural sciences, between logic and rhetoric. ${ }^{2}$ Toulmin writes: "What P. F. Strawson calls a 'conceptual framework,' and Bakhtin - a little misleadingly — an 'ideology,' the theoretical physicist thus calls a 'treatment'" (p. 107; italics mine). A broader notion of ideology would of course situate the merely conceptual framework within a more extended and heterogeneous field. The physicist's treatment, a decision where "the interpretive element is quite explicit," would occupy a different place within a field similarly heterogeneous and extended.

In the absence of a heterogeneous concept of ideology, Toulmin's text produces definitions that keep the ideology-constitutive distinctions between center and periphery, explanation and interpretation, cause and effect intact:

1. Stuart Hall, "The Hinterland of Science: Ideology and the 'Sociology of Knowledge,' "On Ideology, Working Papers in Cultural Studies, no. 10 (Birmingham, 1977), p. 9. See also Douglas Kellner, "A Bibliographical Note on Ideology and Cultural Studies," Praxis 5 (1981): 84-88.

2. See Newton Garver, intro. to Jacques Derrida, "Speech and Phenomena" and Other Essays on Husserl's Theory of Signs, trans. David B. Allison (Evanston, Ill., 1973), for a summary of the opposition between logic and rhetoric in the disciplinary ideology of philosophy. Not only does Garver parallel Toulmin but he also describes Derrida's work as seeking to undo that opposition. Whatever the validity of Garver's broader analysis, it is interesting to speculate what Toulmin would make of such a suggestion of propinquity. I should perhaps add here that Derrida is suspicious of the concept of ideology because, in his view, it honors too obstinate a binary opposition between mind and matter.

Gayatri Chakravorty Spivak is professor of English at the University of Texas at Austin. She is the translator of Jacques Derrida's De la grammatologie and is presently finishing a book in the areas of Marxist feminism and deconstructive practice. Her previous contribution to Critical Inquiry, “ 'Draupadi' by Mahasveta Devi,” appeared in the Winter 1981 issue. 
In dealing with [peripheral factors that may influence the work of professionals], we are centrally concerned with a larger and more turbulent world of causes, for example, the interactions between the professionals and their human contexts, as well as with any consequential influences that contextual factors may exert on the professional argument itself. [Pp. 104-5]

Accordingly, in both today's postmodern natural and human sciences and the critical disciplines of the humanities, we are concerned with a mix, or blend, of explanation and interpretation. [P. 109]

A critical view of the subject of ideology would call the clarity of these distinctions into question and thus ask the critic to address a less simplified view of the world. It would deconstitute and situate (not reject) the "we" who experiences the productivity of alternative investigative postures, the "legitima[cy]" and "power" of the "acceptable standpoints." Such a view does not allow for a personal-subjective category to be set up over against an intellectual-interpretive category either, since it would see complicity between the constitution of subjectivity and the desire for objective identity.

These problematic distinctions are necessary for Toulmin's argument because it cannot accommodate the concept of ideology. The never fortuitous choice of normative metaphors sometimes seems to suggest this necessity: "There is more temptation to present all [author's italics] interpretations in the human sciences as being essentially political in character than there is in the physical sciences. Still, it is a temptation that we ought to resist" (p. 102; italics mine). This resistance wins a space for us where it is possible to overlook the tremendous ideological overdetermination of the relationship between the "pure" and "applied" sciences, as well as their relationship with private- and public-sector technology and the inscription of the whole into the social and material relations of production. All is reduced to the classical split between subject and object-"two-way interactions between the observer and the system being observed" (p. 106). If the clarity of the theory is dependent upon so stringent a reduction, it loses persuasive value when applied to the sociopolitical scene. A statement like the following, concluded from the subject-object premises I quote above, remains merely theoretical, normed into ethical decoration: "That being so, there is, a fortiori, no longer any reason to assume that studying human beings from a scientific point of view necessarily involves dehumanizing them" (p. 106).

Ronald Dworkin attempts to cut loose from the task of recovering the legislator's intention in the interpretation of the law. He takes literary interpretation as a model, however self-divided, and offers us two interesting and related versions of the subject of lawmaking: a pluralized subject that is one link in a chain of supplementations and a double 
subject who is at once writer and reader. I shall give a brief example of how a general theory of ideology would enhance his argument.

Following through the notion of the pluralized subject in the interpretation of the law, Dworkin is obliged to call a halt at a point which is worth remarking:

Perhaps [putting together a collective novel sequentially] is an impossible assignment . . . because the best theory of art requires a single creator or, if more than one, that each have some control over the whole. But what about legends and jokes? I need not push that question further because I am interested only in the fact that the assignment makes sense, that each of the novelists in the chain can have some idea of what he or she is asked to do, whatever misgivings each might have about the value or character of what will then be produced. [P. 193]

That Dworkin has made fiction and the law each other's tenor and vehicle is in itself significant. In this passage yet another possibility is implicit. Legends and jokes are phenomena where the condition-effect relationship with ideology (in the U.S. the preferred word in this case is "culture") is readily granted. The point might be to see that the difference between these phenomena and the novel is, in the ideological view, one of degree rather than of kind. The single author also has only "some idea" of what he is asked to do, for the entire idea is spread like a map across the text of ideology. The nonexhaustive constitution of the subject in ideology (which is in turn constitutive of ideology) would include, in this revised version of Dworkin's argument, the so-called ideology-free language of Western European and U.S. law. It is only a homogeneous, isomorphic, and adequate cause-and-effect view of social production that would advance the doubtful claim that "liberalism can ... be traced [to] ... a discrete epistemological base ... [which] could be carried forward into aesthetic theory and there yield a distinctive interpretive style" (p. 200). The view I am describing would suggest that such items are related as the interanimating complicity of the shifting components of an ideological system. The productive undecidability of the borderlines of politics, art, law, and philosophy, as they sustain and are sustained by the identity of a composite entity such as the state, is operated by the heterogeneous and discontinuous concept of ideology. Lacking such a concept, Dworkin is obliged to indicate it in the name of a unifying philosophy. It is the strength of his essay that the unification is not seen as a necessarily sublating synthesis: "I end simply by acknowledging my sense that politics, art, and law are united, somehow, in philosophy" (p. 200).

If Dworkin, without pronouncing the word, seems to make room for a broader concept of ideology, Donald Davie would choose to "bypass" its workings: "Doubtless such interrelations exist, and doubtless 
they can be exploited to sinister purpose. Rather than inveighing against this, or (with [Stanley] Fish) more or less blithely acquiescing in it, we can best spend our time bypassing the network altogether, as the truly independent and illuminating interpreters always have" (p. 43).

One cannot of course "choose" to step out of ideology. The most responsible "choice" seems to be to know it as best one can, recognize it as best one can, and, through one's necessarily inadequate interpretation, to work to change it, to acknowledge the challenge of: "Men make their own history, but they do not choose the script" (italics mine). ${ }^{3}$ In fact, I would agree with Edward Said that the ideological system that one might loosely name as contemporary USA expects its poets to seem to choose to ignore it and thus allows its businessmen to declare: "Solid business practices transcend ideology if you are willing to work for it."4

Both Hayden White and Said concentrate upon ideological formations - the former with respect to a group identity called "a discipline," the latter with respect to the discipline in the service of the group identity called "the state." I shall not linger on their arguments here. It is my feeling, however, that in the absence of an articulated notion of ideology as larger than and yet dependent upon the individual subject, their essays sometimes seem a tirade against the folly or knavery of the practitioners of the discipline. The relationship between art and ideology-in this case, bourgeois ideology in the broader sense-is T. J. Clark's explicit subject matter. In his comments on Terry Eagleton, Clark suggests that, "in the years around $1910, \ldots$ it was possible for Marxist intellectuals . . . to see themselves as bourgeois . . . [and oppose] the ideologies of a bourgeois élite" (pp. 148-49, n. 6). The critical practice Clark describes is close to what I suggest as an alternative to Davie's conviction of "bypassing" the ideological network or Said and White's ideology-free accusations.

It is Wayne Booth who pronounces the word "ideology" most often; and in his essay, it is the word "language" that performs the curious function of covering over the absence of a broader concept of ideology. In Mikhail Bakhtin's text, language is not immediately understood as verbal discourse. Ideology as language is an effect that assumes a subject for its cause, defining it within a certain convention of signification. For Booth, language as ideology is the expression of a (group) subject who must constantly assure us, and himself, that he is not merely of the group but also unique. There is a moment in the essay when Booth is almost within reach of Bakhtin's position, a position that today would call itself the politics of textuality, seeing that the network of politics-history-

3. Karl Marx, "The Eighteenth Brumaire of Louis Bonaparte," Karl Marx, Frederick Engels: Collected Works, trans. Richard Dixon et al., 15 vols. (New York, 1975-), 2:103; all translated material has been modified when necessary.

4. Armand Hammer, "A Primer for Doing Business in China," New York Times, 11 Apr. 1982. 
society-sexuality, and the like, defines itself in ideology by acknowledging a textual or weblike structure. Booth's language, however, like Toulmin's, articulates Bakhtin's position within a vocabulary of free choice: "Each language we take in is a language, something already blessed or cursed with symbolic richness, with built-in effects of past choices, invitations to new choices, and a knowledge that some choices are in fact better than the others" (I quote from an earlier version of the essay). Bakhtin's implicit dialectical hinging of subject and language in/of ideology seems to elude Booth here.

When Booth thinks of ideology as beliefs and practices rather than, strictly speaking, language or voice, it is possible for him to hint at this dialectical structure: "Ideology springs from and in turn influences systems of belief and human practice" (p. 50).* Yet he constantly reduces the situation of art and ideology to the conscious-unconscious opposition that I invoked at the outset as one of the substitutes for ideology upon the Anglograph scene. Bakhtin is laudable because he "plac[es] as high a value as he does on the deliberate introduction of counter-ideologies," whereas "conventional Marxists [hold that] . . . selves and societies are radically dependent on the ideologies of art" (earlier version). Here consciousness and the unconscious are understood with reference to a prepsychoanalytic model, as if they belonged to a continuous system where the mark of good practice was to raise the unconscious into consciousness. The strongest diagnosis of ideological victimization in this view is: "I confess, with considerable diffidence, that I think the revelation [of Rabelais' double standard] quite unconscious" (p. 65). The sense of ideology as free choice is the goal: "The question we now face, then, as believers in feminist (or any other) ideology, is this: Am I free, in interpreting and criticizing a work of art, to employ that ideology as one element in my appraisal of the artistic value of that work?" (p. 56).

It is not too far from the truth to suggest that this freedom of choice by a freely choosing subject, which operates the essays of Toulmin, Davie, Dworkin, and Booth, is the ideology of free enterprise at workrecognizably a politics of interpretation. That is why we accepted as common sense that the best theory of art required a single author. Within a broad concept of ideology, the subject does not lose its power to act or resist but is seen as irretrievably plural. In that perspective, all novels are seen to be composed as serials by various hands. Dworkin's analogy between literature and the law can, in that perspective, be read differently as a case of this politics of interpretation, just as the novelist and his reader, requiring a single creator and therefore overlooking the novel's being an effect within a larger text, are another case. In a serial novel by various hands of the kind Dworkin presupposes, the narrative is supposed to advance while preserving some presumed unity, whereas in

*Booth has since changed the word "ideology" to "art" in this sentence.-Editor's note 
a series of interpretations of the same law, we have not progress but repetition-each repetition presumably claiming to be most adequate to the ipseity of the law in question. Lawyers, even when they, like Dworkin, grant the actual plurality of interpretations, are bent on the search for the "real" law, the "proper" law, the "best" interpretation, its single true intention. As cases of ideology formation, Dworkin's analogy and its attendant definition of authorship seem to betray their "politics"-free enterprise and the rule of law.

"Betray their 'politics." " A better formulation of this is to be found in Pierre Macherey: "We always eventually find, at the edge of the text, the language of ideology, momentarily hidden, but eloquent by its very absence." Let us consider moments on the edges or borders of some of these essays, the ideological traces that allow them to define their interiors. Such a gesture will yield a hint of their politics as well, a politics of the freely choosing subject who, divining his own plurality, breaks his theory as he takes a stand.

Such a definitive moment comes at the end of Stanley Cavell's piece: "If deconstruction, as in de Man's recommendation of it, is to disillusion us, it is a noble promise and to be given welcome. Disillusion is what fits us for reality, whether in Plato's terms or in D. W. Winnicott's. But then we must be assured that this promise is based on a true knowledge of what our illusions are" (p. 178). I am not altogether convinced by Cavell's reading of deconstruction in this essay, especially when he associates de Man and Derrida without much differentiation. ${ }^{6}$ I will merely remark that the assurance to the subject of true knowledge, a self-evident ideological requirement for self-evidence, is the one thing deconstruction cannot promise. A number of arguments that Cavell undoubtedly can anticipate might be advanced here: there is no disillusion without illusion; a true knowledge of illusions can lead to a knowledge of reality only as that which is not illusion; to predicate reality as the death of illusion is to ignore the syntax or practice that passes from illusion to reality via dis-illusion; not to acknowledge that deconstruction distinguishes itself from dialectics precisely by this attention to the syntax that is otherwise ignored in the interest of the semantics of reality is not to speak of deconstruction at all. ${ }^{7}$ I shall not dwell upon these arguments here but suggest that Cavell's interpretation of voice and writing is also in the interest of this ideological requirement.

5. Pierre Macherey, A Theory of Literary Production, trans. Geoffrey Wall (London, 1978), p. 60; italics mine.

6. See Cavell, "Politics as Opposed to What?" (p. 173). For a discussion of this difference, see my review of Allegories of Reading: Figural Language in Rousseau, Nietzsche, Rilke, and Proust by Paul de Man, Studies in the Novel (forthcoming). See also my "Revolutions That as Yet Have No Model: Derrida's Limited Inc," Diacritics 10 (Winter 1980): 47-48.

7. For an articulation of deconstruction as syntactic or micrological resistance against the hegemony of semantics or macrology, see Derrida, "White Mythology: Metaphor in the Text of Philosophy,” trans. F. C. T. Moore, New Literary History 6 (Autumn 1974): 73-74. 
Cavell writes: "For me it is evident that the reign of repressive philosophical systematizing-sometimes called metaphysics, sometimes called logical analysis - has depended upon the suppression of the human voice. It is as the recovery of this voice (as from an illness) that ordinary language philosophy is ... to be understood" (p. 173). Derrida admires this project and relates it to Nietzsche's attention to the force of language rather than its signification alone. What Derrida critiques is what Cavell seems to be showing here: the tendency common to most radical philosophies, including speech-act theory, to perceive their task as the restoration of voice. The systematic philosophies, on the other hand, although their aura seems to be altogether mediated and therefore akin to the common understanding (here Cavell's) of writing, develop systems which depend upon phonocentrism as their final reference. Thus the commonsense perception-that systematic philosophies suppress and radical philosophies restore voice-depends upon varieties of phonocentric assumptions. "Writing" in this view becomes the name for that which must be excluded so that the interiority of a system can be defined and guarded. "The essential predicate of [the] specific difference" between writing and the field of voice is seen in such a reading as "the absence of the sender [and] of the receiver (destinateur), from the mark that he abandons." 8 The place of such an understanding of writing within a self-professed project of the restoration of speech should be clear.

Writing as the name of that which must be excluded as the other in order to conserve the identity of the same can be related to Macherey's other formulation: "What is important in the work is what it does not say. This is not the same as the careless notation 'what it refuses to say,' although that would in itself be interesting. ... But rather than this, what the work cannot say is important because there the elaboration of the journey is acted out, in a sort of journey to silence." ${ }^{9}$ It is not surprising that, within a definition of writing as a deliberate withholding of voice, the one sense of "turn" - in Thoreau's "You only need sit still long enough in some attractive spot in the woods that all its inhabitants may exhibit themselves to you by turns"- that Cavell does not (cannot?) mention is "trope," the irreducible turn of figuration that is the condition of (im)possibility of any redemption of voice.

It is in terms of saving the freely choosing subject whose concept insinuates itself into the most radical commun(al)ist politics of collectivity that Said uses écriture as a code word suggesting (I cannot be sure, since the word hangs unexplained on the borders of his essay) linguistic reductionism at a second remove. The thumbnail explanation of écriture as the excluded other that I have given above would have helped his gen-

8. Derrida, "Signature Event Context," trans. Jeffrey Mehlman and Samuel Weber, Glyph 1 (1977): 179, 177.

9. Macherey, Theory of Literary Production, p. 86. 
eral argument: "A principle of silent exclusion operates within and at the boundaries of discourse; this has now become so internalized that fields, disciplines, and their discourses have taken on the status of immutable durability" (p. 16).

Since I find myself more than usually sympathetic with Said's position, I must point out another mark of ideology at work in his essay. The essay is written by a subject who is not only freely choosing but is also a star within a star system. There is no recognition or support here for the thousands of teachers and students across the country who are attempting to keep alive a critical cultural practice. Their track is to be picked up not only in journals such as Radical Teacher or Radical America but in course syllabi, in newsletters, and increasingly on the rolls of young teachers denied tenure. In order to recognize these workers, pedagogy as political interpretation must be seriously considered. A phenomenon cannot be nonexistent when a political spectrum extending from Michael Harrington to U.S. News and World Report accounts for its workings. ${ }^{10}$ Said's statement that "the Left [is] in a state of intellectual disarray" is indeed true with respect to political sectarianism (p. 3). But if our own field of work is seen as outside of generalizations such as "high culture here is assumed to be above politics as a matter of unanimous convention" and also outside of the perspective of self-described Marxist "celebrities" (the third item in the title of Regis Debray's Teachers, Writers, Celebrities, which Said cites) who seem obliged to hear themselves as lonely personalities proselytizing in the wilderness, then the extent of our predicament, that all this effort goes awry, is seen as a much more menacing problem.

An awareness of solidarity with the ongoing pedagogic effort would have allowed Said to step out of the chalk circle of the three thousand critics and recognize that the task- "to use the visual faculty (which also happens to be dominated by visual media such as television, news photography, and commercial film, all of them fundamentally immediate, 'objective,' and ahistorical) to restore the nonsequential energy of lived historical memory and subjectivity as fundamental components of meaning in representation"-is attempted every day by popularculture teachers on the Left (p. 25). I quote Tabloid as a metonym: "Many of our articles over the past months have given examples of this daily subversion-women in the home mutating the 'planned' effect of TV soap operas, political activists creating pirate radio stations, the customization of cars, clothing, etc." 11

One of the most productive moments at the "Politics of Interpreta-

10. See Michael Harrington, "Getting Restless Again," New Republic, 1 and 8 Sept. 1979, and David B. Richardson, "Marxism in U.S. Classrooms," U.S. News and World Report, 25 Jan. 1982.

11. “On/Against Mass Culture III: Opening Up the Debate," Tabloid 5 (Winter 1982): 1. 
tion" symposium was an exchange between Davie and Said. Davie singled out Said's work for Palestine (Lebanon in Davie's script) as an example of patriotism. Said appropriately amended that praise by suggesting that he was working for the Palestinian state to establish itself so that he could then become its critic. Consciousness of national identity is marked by the use to which it is put. The thin line between national liberation and maintenance of the ideology of the state must be kept clean by the critic's vigilance. Otherwise, Davie's endorsement of patriotism becomes the condition and effect of a political ideology that denies the workings of an economic multinationalism. The production of archaic politico-nationalist explanations, irreducibly asymmetrical with the economico-multinationalist network, shows itself most brutally as war and most divisively as the indoctrination of the labor force. The mechanics of that denial are implicit in Davie's lament:

By thus loftily declaring ourselves "citizens of the world" [which is of course not what I suggest above] we cut ourselves off not just from the majority of our fellow-citizens at the present day but from the far more numerous multitude of the dead. For there can be no doubt that to Virgil and Dante and Machiavelli, to Milton and Wordsworth, to Washington and Jefferson and Walt Whitman, the patria was meaningful, and its claims upon us were real and must be honoured, in just the ways that this sort of modern enlightenment refuses to countenance. [P. 29]

The march of capital has cut Davie off from the network that sustains and is sustained by a full-fledged patriotic ideology. He undoubtedly has no objection to the mode of sociomaterial production (since his deliberate stance is to bypass it) that shores him up in Tennessee or in front of a high-toned audience in Chicago. Nearly all the candidates on his list had intervened in rather than bypassed social relations of production in their time. At any rate, it was within that entire network that the "patriotism" of earlier generations could find its function and place. Davie as expatriate, consumer, taxpayer, voter, and investor has (been) moved into so different a network that merely to hang on to the one item on the list that seems sentimentally satisfying will produce, at best, a self-congratulatory simulacrum of community with the illustrious dead.

By force of the ideology appropriate to his place in the world, Davie unwittingly inhabits a country different from merely England. Let us look for a moment at the way he outlines that country, reminding ourselves that it is at those borders of discourse where metaphor and example seem arbitrarily chosen that ideology breaks through.

For when a poet or a literary scholar, British or American or Australian, addresses not his fellow-Britons or his fellow-Americans or fellow-Australians but the international community of literary 
scholars, that intention shows up at once in the sort of English that he uses. [P. 29, italics mine]

Must we assume that British English, American English, and New Zealand English are on the way to becoming distinct languages, as Romanian and Portuguese once became distinct languages by diverging differently from the parent stock of Roman Latin? [P. 35]

The point is not that the case would be altered (as indeed it would, in interesting ways) if the Caribbean, the Indian subcontinent, and Kenya-Uganda-Tanganyika (the colonial name for Tanzania)—also English speaking-were introduced into the company. The point is that a discourse such as Davie's, ignoring the difference between the linguistic self-concept of national liberation and patriotism, "naturally" or "only by chance" excludes them from the English-speaking Union. Indeed, to alter one of Davie's sentences a little: "[my] suggestion will seem bizarre except to those . . . who [are involved with admission into and granting degrees from U.S. English departments]" (p. 35). Davie's entire argument would have to be recast if the candidate were not "Georges [from] Bucharest" or "Lucille in Vincennes" but Echeruo from Nigeria or Towheed in Pakistan. Of course "all the languages are precious, every one is unique, and so no one is replaceable by any other" (p. 29). But if one examines the figures of foreign-language enrollment in the Chronicle of Higher Education or comparable journals, one knows instantly that they are not in fact equally precious, and the demand depends on the politico-economic text. One need only think of the case of Japanese, Arabic, and Persian in recent years. From a somewhat different point of view, one might think of the status of a Shakespeare scholar who has read all of his Shakespeare in Bengali and a scholar of Bengali culture who has had a semester's Bengali in a U.S. graduate school. (This is not an imaginary example, although it "will seem bizarre except to those of us who [are involved in judging fellowship applications on the national level].")

There is disciplinary ideology in Davie's certainty of the secure role of the poet in contemporary society; in Said's conviction that the literary critic rather than the other human scientists are the custodians of sociopolitical interpretation; and, malgré tout, in White's admonition that "to appeal to sociology, anthropology, or psychology for some basis for determining an appropriate perspective on history is rather like basing one's notion of the soundness of a building's foundations on the structural properties of its second or third story" (p. 130).

But the most interesting sign of disciplinary privileging is found in Julia Kristeva's "Psychoanalysis and the Polis." At the end or center of delirium, according to Kristeva, is that which is desired, a hollow where meaning empties out in not only the presymbolic but the preobjective, "the ab-ject." (A deconstructive critique of thus "naming" an un- 
differentiated telos of desire before the beginning of difference can be launched but is not to my purpose here.) The desire for knowledge involved in mainstream interpretation (which Kristeva calls "Stoic" by one of those undocumented sweeping generalizations common to a certain kind of "French" criticism) shares such a hollow center and is thus linked with delirium. Certain kinds of fiction writers and, one presumes, analysands and social engineers try to dominate, transform, and exterminate improper "objects" awakened in the place of the abject. The psychoanalyst, however, wins out over both mad writer and man of politics. "Knowing that he is constantly in abjection [none of the problems of this position is discussed in Kristeva's text ${ }^{12}$ and in neutrality, in desire and in indifference, the analyst builds a strong ethics, not normative but directed, which no transcendence guarantees" (p. 92; italics mine). This is the privileged position of synthesis within a restrained dialectic: the psychoanalyst persistently and symmetrically sublates the contradiction between interpretation and delirium. To privilege delirium (interpretation as delirium) in the description of this symmetrical synthesis is to misrepresent the dialectic presented by the essay, precisely in the interest of a politics that can represent its excluded other as an analysis that privileges interpretation. It should also be mentioned, of course, that the indivisibility and inevitability of the archaic (Christian) mother comes close to a transcendental guarantee. To know her for what she is, rather than to seek to transform her, is the psychoanalyst's professional enterprise.

I cannot pretend that the born-again recovery of Christianity and particularly Mariolatry in the latest Tel Quels is not disturbing to me. Not only does Kristeva fail to question the sociohistorical symptomaticity of psychoanalysis as a disciplinary practice but she has this to say about the abject mother of psychoanalysis and the messianic role of psychoanalysis as sublation of Christianity:

Our cultural orb is centered around the axiom that "the Word became flesh." Two thousand years after a tireless exploration of the comings and goings between discourse and the object [traditional interpretation] to be named or interpreted, an object which is the solicitor of interrogation, we have finally achieved a discourse on discourse, an interpretation of interpretation. For the psychoanalyst, this vertigo in abstraction is, nevertheless, a means of protecting us from a masochistic and jubilatory fall into nature, into the full and pagan mother. [P. 87, italics mine]

Who is the excluded other that privileges interpretation? Not the writer, in this case Louis Ferdinand Céline, whose abject-transcending

12. A similar problem is encountered with White's offer of a running narrative as a critique of the narrativization of the discipline of history. 
paranoia, otherwise known as anti-Semitism, the analyst-critic interprets for us through a somewhat positivistic analysis of sentence structure. The ideological scapegoat, hanging out on the borders, is that old favorite, Karl Marx. Kristeva makes an unproblematic analogy between the single-person situation of analysis and the vastly multitudinous, multiracial, and multinational (including "pagan" cultures) political arena and gives us a species of Reichian diagnosis of the revolutionary leader's promise of a utopia in the place of abjection. The psychoanalyst by contrast is polytopian (not merely the Second Coming of the Hebraic Christ but perhaps also the fulfillment of the Hellenic Homer, who asked the full pagan mother-Muse to sing in him the poly-tropic-much tricking, in many tropes-Odysseus, at the beginning of his epic). It would be interesting to follow this homogenizing analogy and ask: Who in politics takes the place of the analyst who, knowingly, sometimes participates in the patient's delirium and draws back just enough to offer the healing interpretation which, "removing obvious, immediate, realistic meaning from discourse ... [reveals] every phantasm . . . as an attempt to return to the unnameable" (pp. 85-86)? White argues that the interpretation of history as sublimely meaningless is "conventionally associated with the ideologies of fascist regimes" (p. 130). "Such a mobilizing interpretation can be called revolution or demagogy," Kristeva writes (p. 86). How can one take such an alternative seriously?

At any rate, to prove that political interpretations cannot be true, Kristeva argues as follows: "Unlike the analytic dynamic, however, the dynamic of political interpretation does not lead its subjects to an elucidation of their own (and its own) truth. . . . Of course, no political discourse can pass into nonmeaning. Its goal, Marx stated explicitly, is to reach the goal of interpretation: interpreting the world in order to transform it according to our needs and desires" (pp. 86-87). One might of course wonder if leading a subject to truth is not a species of transformation of the subject or, yet, if what Marx says about politics is necessarily the truth of all political discourse.

Let us rather investigate Marx's "explicit statement." Is it the eleventh of Marx's Theses on Feuerbach that Kristeva quotes in the epigraph? "Up until now philosophers have only interpreted the world. The point now is to change it [Die Philosophen haben die Welt nur verschieden interpretiert, es kömmt drauf an, sie zu verändern]" (italics mine). As close a reader as Kristeva should note that the relationship between interpretation and change in that statement is exceedingly problematic. Ankommen auf in this context probably means "what matters" (within philosophic effort). Even in the most farfetched reading, such as "advent" (ankommen, or arrival), a contrastive juxtaposition can hardly be avoided. "To interpret . . . in order to transform" (italics mine) seems wishful thinking. The point can also be made that these theses, aphoristic statements parodying and imitating Luther, were written in 1845. 
Marx had not yet seen a "revolution," not even 1848. It would be like taking an epigraph from Studies in Hysteria, basing an entirely unfavorable comparison upon it, and clinching the case with "Freud has explicitly stated. ..."

I have suggested that in Kristeva's essay psychoanalysis is shown to sublate the contradiction between interpretation and delirium. When Kristeva claims that political discourse cannot pass into nonmeaning, it remains to be asked how it can be posited that the Hegelian dialecticMarx's morphology-does not accommodate a negative moment, a passing into nonmeaning, in order to accede to truth. I have suggested elsewhere that Marx's theory of practice goes beyond this restrained dialectic. ${ }^{13}$ But I have tried to show here that even if Marx is not given the benefit of that doubt and even on Kristeva's own terms, it would be inadvisable to attempt to critique Marx with so little textual evidence. If one wishes to support a major component of one's argument on Marx, he demands at least as much attention as Céline.

I am not altogether comfortable with Louis Althusser's theory of the epistemological cut in Marx's work, although I am moved by his explanations in Essays in Self-Criticism. It is, however, well known that the generation influenced by Althusser's teaching, dissatisfied with the failure of 1968 and the subsequent move on the French Left toward a nonrevolutionary Eurocommunism, turned away from the Capital and Marx's later writings as endorsed by Althusser and toward, especially, the 1844 manuscripts, as had Jean-Paul Sartre an intellectual halfgeneration before Althusser; unlike Sartre, this younger generation sought to find in these manuscripts negative proof of an irreducible will to power. When Kristeva writes "this abject awakens in the one who speaks archaic conflicts with his own improper objects, his ab-jects, at the edge of meaning, at the limits of the interpretable [and] it arouses the paranoid rage to dominate those objects, to transform them," she is writing not only of Céline's anti-Semitism but also of the revolutionary impulse (p. 91). What is at stake here is a politics of interpretation.

The ideological exclusion of a "Marx" as other operates also in White's essay. Although no textual analysis is forthcoming, the assertion that Marx was interested in making sense out of history seems to be indisputable. But I am troubled when White submits that this urge to explain history arose in the nineteenth century, that Marx was caught up in that specific moment of historiography's practice, and that the Jews regarded history as a meaningless sublime spectacle until the establishment of Israel. Surely the grand plans of Judeo-Christian psychobiography and historiography should not be thus dismissed! I am not suggesting, as Kristeva does for psychoanalysis, that the discipline of

13. See my "Il faut s'y prendre en se prenant à elle," in Les Fins de l'homme, ed. Philippe Lacoue-Labarthe and Jean-Luc Nancy (Paris, 1981). 
history in Europe is a fulfillment of these earlier plans. I am merely indicating that the discipline of history did not suddenly fall upon previously virgin ground.

Whatever the truth of the assertion that the pursuit of meaning links Marx with the bourgeois historian (as it links him with the antiSemitic writer in "Psychoanalysis and the Polis"), it seems bizarre to place him within the change from the sublime to the beautiful without some textual consideration. On the other hand, if one sees White's and Kristeva's moves as part of a contemporary academic-ideological network of explaining Marx away by the most general possible means as a foreclosure of exclusion, it becomes less odd. Some questions remain. Does the sublime historian's promise of a perception of meaninglessness not assume a preliminary understanding of what meaning in/of history might be? According to White, "the theorists of the sublime had correctly divined that whatever dignity and freedom human beings could lay claim to could come only by way of what Freud called a 'reactionformation' to an apperception of history's meaninglessness" (p. 128). I will not bring up once again the vexed question of the passage from individual to group psychology here. I will sum up this part of my reading with the following suggestion: If, for political reasons touched upon by Clark and Said in their different ways, it is expedient to valorize the savant who can apperceive meaninglessness, then both Kristeva and White, in their different ways, claim "meaninglessness" too easily. I have tried to indicate this in my discussion of Kristeva. In White, "confusion," "uncertainty," and "moral anarchy" are equated with meaninglessness. Such a loose colloquial use deprives the word of any theoretical value.

By way of conclusion I will consider woman as the ideologically excluded other. Although I have some problems with Booth's essay, let me at the outset express my solidarity with his effort to correct this situation.

Almost all the personal pronouns in all the essays are "he." I am not asking for the quick fix of a mandatory "he or she." Just as, if the West Indian were introduced into Davie's script or the Arab academic style into Cavell's hilarious list of (English, French, and U.S.) academic styles, the argument itself would have to accommodate an otherwise unwitting race privileging-I think in twenty years the Japanese will come to inhabit these lists "naturally"-so also, if the "she" is seriously introduced into these essays, the general argument might need to change its shape. I believe it is with this sense of things that I find myself violated by the impregnable agent of an apparently benign statement such as the following by White: "But imagination is dangerous for the historian, because he cannot know that what he has imagined was actually the case, that it is not a product of his 'imagination' in the sense in which that term 
is used to characterize the activity of the poet or writer of fiction" (p. 123; italics mine). The masculist critic might well say, What am I going to do if an objection is brought against the very grain of my prose? Indeed, the feminist critic would urge, if he became aware that the indefinite personal pronoun is "produced-producing" rather than "natural," then he would also realize that, in this specific case, for example, since woman's place within the discipline and as subject of history is different from man's all along the race-class spectrum, and since a woman's right to "imagine" history is fraught with perils of a different kind, the validity of the critic's entire argument is put into question by that objection. As long as feminism is considered a special-interest glamorization of mainstream discourse (and I am grateful again to Booth for revealing the way feminist approaches are discussed in "academic locker rooms"), this problem will go unrecognized. And within the tacitly acknowledged and bonded enclosure of masculist knowledge-production, a partial (masculist) account of intellectual history will, even as it critiques the narrative mode of "doing history," persistently imply that it is larger than the "whole"- the latter being an account that will confront the fundamental problem of sexual difference in material and ideological production. No history of consciousness can any longer be broached without this confrontation.

The problem cannot be solved by noticing celebrated female practitioners of the discipline, such as Hannah Arendt. The collective situation of the ideologically constituted-constituting sexed subject in the production of and as the situational object of historical discourse is a structural problem that obviously goes beyond the recognition of worthy exceptions. This critique should not be understood as merely an accusation of personal guilt; for the shifting limits of ideology, as I have suggested earlier, are larger than the "individual consciousness." Understood as such, my desperation at the smooth universality of Dworkin's discussion of law as interpretation will not seem merely tendentious. For it is not a questioning of the power of Dworkin's thesis; it is an acknowledgment that, if woman as the subject in law, or the subject of legal interpretation, is allowed into the argument in terms of the differential ethico-political dimension of these relationships, then the clarity might have to be seen as narrow and gender-specific rather than universal. (I am of course not mentioning the possibility that the eruption of JudeoChristian sanctions within the recent debate on abortion shows how questions of sexual difference challenge the secular foundation of Western law. ${ }^{14}$

Let us consider Davie's two quick stabs at feminists before turning to woman in the essays by Kristeva, Said, and Booth. By way of introduc-

14. See, e.g., Joel Feinberg, ed., The Problem of Abortion (Belmont, Calif., 1973), and Marshall Cohen et al., eds., Rights and Wrongs of Abortion (Princeton, N.J., 1974). 
tion, let us insist that the word "patria" is not merely masculine in gender but names the father as the source of legitimate identity. (The appropriation of mother figures into this naming is similarly related to the place of Arendt in White's essay.) One way of explaining this would be to look again at Vico's fable of the origin of civil society-the patricians-in The New Science. ${ }^{15}$ Here I shall point at the accompanying "hieroglyph or fable of Juno hanging in the air with a rope around her neck and her hands tied by another rope and with two heavy stones tied to her feet.... (Juno was in the air to signify the auspices essential to solemn nuptials.... She had a rope about her neck to recall the violence used by the giants on the first wives. Her hands were bound in token of the subjection of wives to their husbands. ... The heavy stones tied to her feet denoted the stability of marriage.)"16

Davie's first stab comes when he reproaches feminists for not differentiating among women of different countries:

Where is it acknowledged, for instance, in the vocabulary of feminism that "woman," as conceived by an American writing about Italians, cannot help but be significantly different from "woman" as conceived by an Italian looking at Americans? Or again, an Italian woman may well, we must suppose, be an Italian patriot; but where, in the current vocabulary of feminists, is that dimension of her "woman-ness" allowed for? Let it be acknowledged only so as to be deplored; but let it in any event be acknowledged. At the moment, it isn't. [P. 34]

This is of course a ridiculous mistake. The heterogeneity of international feminisms and women's situations across race and class lines is one of the chief concerns of feminist practice and theory today. To document this claim would be to compile a volume of bibliographical data. ${ }^{17}$ And no feminist denies that women's as well as men's con-

15. For an analysis, see my "Explanation and Culture: Marginalia," Humanities in Society 2 (Summer 1979): $217 \mathrm{ff}$.

16. Giovanni Battista Vico, The New Science, trans. Thomas Goddard Bergin and Max Harold Fisch (Ithaca, N.Y., 1968), p. 175. Said refers to the Viconian passage on the origin of the patricians without any reference to its sex-fix ("Opponents, Audiences, Constituencies, and Community," pp. 10-11).

17. I will give Davie a start. See Elaine Marks and Isabelle de Courtivron, eds., New French Feminisms: An Anthology (Amherst, Mass., 1980); Signs 3 (Autumn 1977), special issue on Women and National Development; Julia Kristeva, About Chinese Women, trans. Anita Barrows (New York, 1977); Nawal El Saadawi, The Hidden Face of Eve: Women in the Arab World, trans. and ed. Sherif Hetata (London, 1980); Lesley Caldwell, "Church, State, and Family: The Women's Movement in Italy," in Feminism and Materialism: Women and Modes of Production, ed. Annette Kuhn and Annmarie Wolpe (London, 1978); Gail Omvedt, We Will Smash This Prison! Indian Women in Struggle (London, 1980); Cherrie Moraga and Gloria Anzaldúa, eds., This Bridge Called My Back: Writings by Radical Women of Color (Watertown, Mass., 1981); and Spivak, "Three Feminist Readings: McCullers, Drabble, Habermas," Union 
sciousnesses can be raised with reference to such notions as patriotism or total womanhood.

The second stab is with respect to Said's mother:

When his Palestinian parents married, they had to register the marriage with the authorities of what was at that time a British mandate. The British officer, having registered the marriage, then and there tore up Mrs. Said's Palestinian passport, explaining that by doing so he made one more vacancy in the quota of permitted immigrants to Palestine from among the dispossessed of wardevastated Europe. The feminist response to this- "Aha, it was the wife's passport that was destroyed, not the husband's"-wholly fails to recognize the outrage that Mrs. Said felt, which her son now feels on her behalf. For if the law had been such that the husband took his bride's name, so that it was the man's passport that was destroyed, the outrage would have been just the same. [P. 34]

If I may descend into unseemly levity for a moment, I will quote my long-deceased father: "If Grandmother had a beard, she would be Grandfather." For the point is precisely that in a patriarchal society there are no such laws. ${ }^{18}$

Said calls for a criticism that would account for "quotidian politics and the struggle for power" (p. 14). At its best, feminist hermeneutics attempts precisely this. Part of the attempt has been to articulate the relationship between phallocracy and capital, as well as that between phallocracy and the organized Left. I refer Said to two representative titles: Zillah R. Eisenstein's Capitalist Patriarchy and the Case for Socialist Feminism and the collection Beyond the Fragments: Feminism and the Making of Socialism.

I have been commenting on the politics of exclusion. The deliberate politics of inclusion can also turn into an appropriative gesture. We see it happen in Terry Eagleton's Walter Benjamin; or, Towards a Revolutionary Criticism. "Let us briefly imagine," Eagleton writes,

what shape a "revolutionary literary criticism" would assume. It would dismantle the ruling concepts of "literature," reinserting

Seminary Quarterly Review 35 (Fall-Winter 1979-80): 15-34, "French Feminism in an International Frame," Yale French Studies 62 (1981): 154-84, and “'Draupadi' by Mahasveta Devi," Critical Inquiry 8 (Winter 1981): 381-402.

18. And to verify the extension of that turf, Davie might consult an essay by a respected male anthropologist who is not necessarily a feminist, Maurice Godelier, "The Origins of Male Domination," New Left Review 127 (May-June 1981): 3-17. A similar objection could be brought to Davie's insistence that there was nothing of the colonizer in the behavior of the British officer. Situationally and personally, perhaps not. But it is not without significance that it was the British rather than the Palestinian who had the power to decide. 
"literary" texts into the whole field of cultural practices. It would strive to relate such "cultural" practices to other forms of social activity, and to transform the cultural apparatuses themselves. It would articulate its "cultural" analyses with a consistent political intervention. It would deconstruct the received hierarchies of "literature" and transvaluate received judgments and assumptions; engage with the language and "unconscious" of literary texts, to reveal their role in the ideological construction of the subject; and mobilize such texts, if necessary by hermeneutic "violence," in a struggle to transform those subjects within a wider political context. If one wanted a paradigm for such criticism, already established within the present, there is a name for it: feminist criticism. ${ }^{19}$

Just as Eagleton earlier accommodates deconstruction as a property of the dialectic, so does he accommodate feminism as a movement within the evolution of Marxist criticism. ${ }^{20}$ The vexed question of how to operate race-, class-, and gender-analyses together is not even considered, for the safe space of feminist critique within "cultural practice" is assured even as that critique is neutralized by such a situating gesture. In a moment, however, the motives for this accommodation may themselves be situated within an ideological ground. Having praised feminist criticism (carrying his own name on the list by proxy; see n. 20) for its revolutionary-Marxist potential, Eagleton proceeds to trash it in three paragraphs: his main contention, feminism is theoretically thin, or separatist. Girls, shape up!

If I were writing specifically on Eagleton on feminism, I should question this unexamined vanguardism of theory. In the present context, other questions seem pertinent. First, where does this undifferentiated, undocumented, monolithic feminist criticism hang out? The gesture of constituting such an object in order that it may be appropriated and then devalued has something like a relationship with the constitution of a monolithic Marx, Marxism, Marxist critics that we have encountered in most of these essays. Davie's reprimand that we do not distinguish among women becomes all the more risible in this context. Even to Booth's benevolent impulse one must add the cautionary word, lest it share a niche with Eagleton's strategy here: woman's voice is not one voice to be added to the orchestra; every voice is inhabited by the sexual differential.

19. Terry Eagleton, Walter Benjamin; or, Towards a Revolutionary Criticism (London, 1981), p. 98.

20. It is a place-the end of the line of the evolution of Marxist criticism-previously named with his own patronymic: "Let us review some of the names of the major Marxist aestheticians of the century to date: Lukács, Goldmann, Sartre, Caudwell, Adorno, Marcuse, Della Volpe, Macherey, Jameson, Eagleton” (Eagleton, ibid., p. 96). It should be mentioned that Eagleton surrounds the implicit evolutionism of his argument with many apologies to the contrary. 
Why is it that male critics in search of a cause find in feminist criticism their best hope? Perhaps because, unlike the race and class situations, where academic people are not likely to get much of a hearing, the women's struggle is one they can support "from the inside." Feminism in its academic inceptions is accessible and subject to correction by authoritative men; whereas, as Clark has rightly pointed out, for the bourgeois intellectual to look to join other politico-economic struggles is to toe the line between hubris and bathos.

Perhaps a certain caution can be recommended to Kristeva as well. I have suggested that she lacks a political, historical, or cultural perspective on psychoanalysis as a movement. I would also suggest that the notion that the ultimate object-before-objectity is invariably the Mother is fraught with the monolithic figure of Woman rather than women heterogeneously operating outside of masculist kinship inscriptions. No neologism is merely etymological. No nomenclature is ideologically pure. It is therefore necessary to question, paleonymically, why the archaic mother is called, precisely, ab-ject. (The argument that it can mean "thrown away from"- - as "object" means "thrown toward"-by its Latin derivation is not enough.)

I have tried to read some aspects of the interpretive politics that seemed to produce and was produced by the symposium on "The Politics of Interpretation." I have pointed first at the usefulness of a broader notion of ideology and then proceeded to notice some of the marks of ideology at work: conserving the sovereign subject; excluding a monolithic Marx(ism); and excluding or appropriating a homogeneous woman. But perhaps the strongest indicator of another item on the ideological agenda-the implicit race idiom of our politics-is the explicit charge I failed to fulfill.

In a report on our symposium in the Chicago Grey City Journal, Ken Wissoker said about my inclusion in the panel: "She was there, I assume, because she translated Derrida's Of Grammatology." 11 Reading those words, Elizabeth Abel's long and gracious letter of invitation to me came to mind. It was my point of view as a Third World feminist that she had hoped would enhance the proceedings. Apart from a pious remark that the maids upstairs in the guest quarters were women of color and a show of sentiment, involving Thomas Macaulay, when Said and I held the stage for a moment, the Third World seemed ex-orbitant to our concerns. As I reflect upon the cumulative politics of our gathering, that seems to strike the harshest note.

21. Ken Wissoker, "The Politics of Interpretation," Chicago Grey City Journal, 24 Nov. 1981. 